\title{
Immuno-chromatographic Cortisol Biosensor Using Enzyme-labeled Conjugate
}

\author{
Yusuke Tahara, Suguru Yoshikawa, Vivek Shetty ${ }^{1}$ and Masaki Yamaguchi* \\ Graduate School of Engineering, Iwate University, 4-3-5 Ueda, Morioka 020-8551, Japan \\ ${ }^{1}$ School of Dentistry, University of California, Los Angeles, \\ 10833 Le Conte Avenue, Los Angeles 90095-1668, USA
}

(Received November 10, 2009; accepted January 19, 2010)

Key words: cortisol, conjugate, stress, biosensor, immuno-chromatograph, test strip

To replace time-consuming laboratory analysis and facilitate point-of-care measurement of cortisol, we developed an immuno-chromatographic biosensor system utilizing disposable test strips and an optical analyzer. To realize an immunochromatographic test strip for competitive and enzyme reactions, a glucose oxidase (GOD)-cortisol conjugate was newly synthesized. Moreover, a cortisol biosensor system consisting of a disposable test strip $\left(5 \times 1.5 \times 50 \mathrm{~mm}^{3}\right)$ and a monitor was fabricated. Considering the error bar (SD) of reflectances, the cortisol concentrations were distinguished by 0,5 , and $10 \mathrm{ng} / \mathrm{ml}$. Thus, it was indicated that a three-scale semiquantitative analysis of cortisol concentrations, such as low, middle, and high between 1 and $10 \mathrm{ng} / \mathrm{ml}$, could be possible in the analysis. Our findings indicate the potential utility of the cortisol biosensor for point-of-use measurements in hospitals.

\section{Introduction}

Saliva has great potential as a biofluid for the noninvasive, point-of-care testing of human disease. ${ }^{(1-3)}$ Salivary cortisol, in particular, is a major neuroendocrine correlator of the neuroendocrine stress response and has been widely and increasingly studied as a stress biomarker. ${ }^{(4)}$ The testing of salivary cortisol levels is particularly attractive because it avoids the need for venipuncture and is well suited for collecting multiple samples in a nonintrusive manner. Owing to its distinct features as a key biomarker of an individual's stress response, cortisol is the increasing focus of psychobiological stress research. (i) Salivary cortisol has a simple relationship with corticotropin-releasing hormone; (5) (ii) there is a close correlation between plasma-free serum and saliva cortisol levels; ${ }^{(6)}$ and (iii) concentration levels between $1-8 \mathrm{ng} / \mathrm{ml}$ in healthy adults $(1 \mathrm{ng} / \mathrm{ml}=0.1$ $\mu \mathrm{g} / \mathrm{dl}=362 \mathrm{pmol} / \mathrm{l})$ render it attractive for measurement as a biological marker. ${ }^{(7)}$

An increasing body of literature documents the relationship between cortisol concentration and stress-related diseases, including irritable bowel syndrome (IBS), ${ }^{(8)}$ chronic fatigue syndrome (CFS), ${ }^{(9)}$ and posttraumatic stress disorder (PTSD). ${ }^{(10)}$ For

*Corresponding author: e-mail: masakiy@iwate-u.ac.jp 
example, the salivary cortisol level (20:00h) is significantly low in an IBS patient, 3.57 $\mathrm{ng} / \mathrm{ml}$, than in a healthy subject, $6.40 \mathrm{ng} / \mathrm{ml} .^{\left({ }^{(8)}\right.}$ Another study has shown the relationship of cortisol levels during sleep with IBS. ${ }^{(11)}$ The attractiveness of salivary cortisol as a biological indicator notwithstanding, contemporary laboratory techniques usually involve testing in centralized laboratories and elaborate enzyme-linked immunosorbent assays (ELISAs). The lag times in reporting results also minimize opportunities for early identification and intervention. Thus, the development of a readily available, easy-touse analytic and downsized device for on-site diagnosis designed to measure and rapidly report cortisol levels would have a great impact on future research and care of subjects with stress-related disorders.

The speed and selectivity of immunological reactions are particularly attractive as a strategy for the molecular recognition of salivary cortisol. Because cortisol is a monovalent antigen with a low molecular weight (362.47), highly sensitive immunosensors are difficult to obtain. An approach involving a noncompetitive immunoassay such as an open-sandwich enzyme immnunoassay is proposed.(12) However, this method can only be utilized in the laboratory. Consequently, highly sensitive immunosensors have been designed by synthesizing enzyme-labeled antigen conjugates for use in competitive binding assays. Peroxidase (EC 1.11.1.7)-cortisolconjugate, ${ }^{(13)}$ aequorin (EC 1.13.12.5)-cortisol-conjugate, ${ }^{(14)}$ and colloidal gold conjugate $^{(15)}$ are the known labeled antigens. Various types of immunoassay for cortisol measurement, such as using an SPR biosensor ${ }^{(16)}$ and capillary electrophoretic enzyme immunoassay, ${ }^{(17)}$ have been proposed to improve the measurement range, detection limit, and measurement time. However, a salivary cortisol biosensor that addresses the limitations of conventional laboratory analysis has not yet been reported.

Our research goal was to develop and demonstrate the utility of a novel immunochromatographic biosensor for the point-of-care testing of salivary cortisol. To this end, we synthesized an enzyme-labeled cortisol conjugate that is derived from the specificity of antigen-antibody reactions. Glucose oxidase (GOD; EC 1.1.3.4), a commonly used enzyme in biosensors, ${ }^{(18)}$ was used an enzyme label because of its relatively high enzymatic activity. The final biosensor system comprised of a dry-chemistrybased colorimetric immuno-chromatographic test strip and a corresponding reader incorporating an optical analyzer used for semiquantitative interpretation.

\section{Material and Methods}

\subsection{Synthesis of GOD-cortisol conjugate}

GOD catalyzes the oxidation of $\beta$-D-glucose to D-glucono- $\delta$-lactone and hydrogen peroxide. The GOD-cortisol conjugate was synthesized using adipic acid dihydrazide (ADH) as a linker. ${ }^{(19,20)}$ First, GOD was modified with an aldehyde to synthesize GODADH. A solution consisting of $10 \mathrm{mg}$ of GOD, $10 \mu \mathrm{l}$ of $0.1 \mathrm{M}$ sodium meta-periodate, and $1 \mathrm{ml}$ of distilled water was incubated at room temperature for $30 \mathrm{~min}$. The solution was equilibrated with $10 \mathrm{mM}$ ammonium carbonate $(\mathrm{pH} \mathrm{9.3)} \mathrm{and} \mathrm{filtered} \mathrm{through}$ a column (Sephadex G-25, GE Healthcare Ltd., UK). The yellow-colored fraction containing GOD-aldehyde was collected in a vial (Fig. 1(a)). 


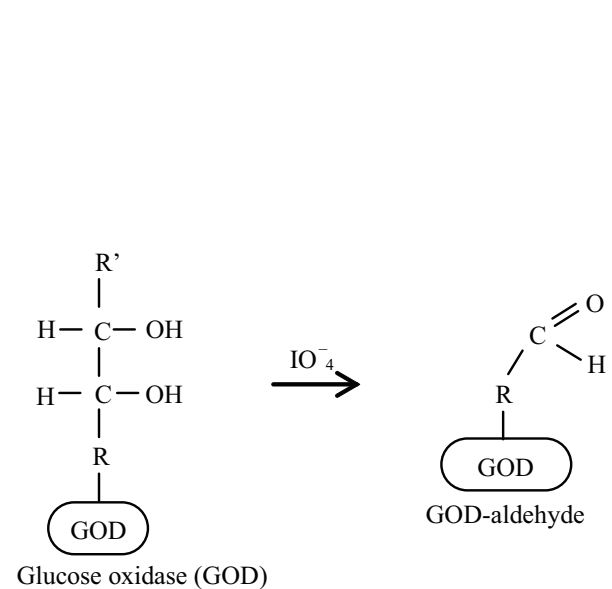

(a)
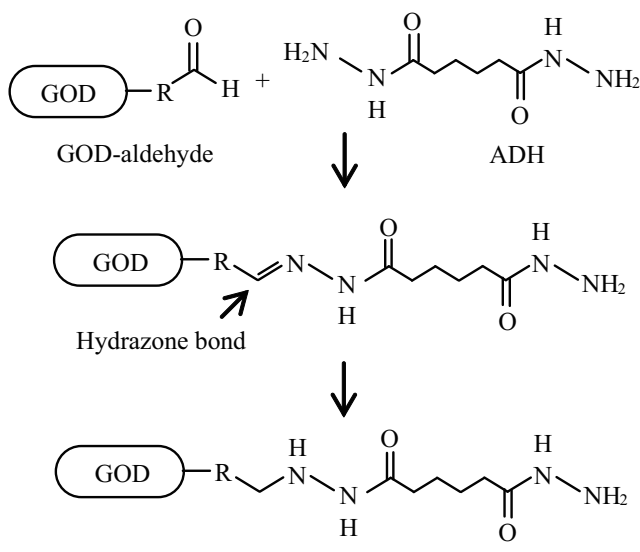

GOD-ADH

(b)

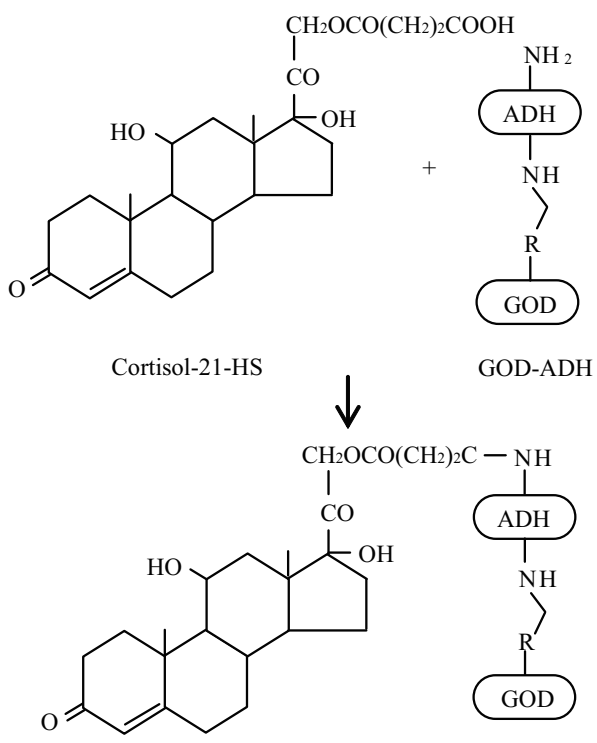

(c)

Fig. 1. Synthesis of the GOD-cortisol conjugate. (a) Modification of GOD-aldehyde, (b) bonding of GOD-aldehyde and ADH, (c) bonding of cortisol-21-HS to GOD-ADH. R and R': alkyl group, GOD: glucose oxidase, ADH: adipic acid dihydrazide.

Next, GOD and ADH were joined by forming a hydrazone bond between them. A solution consisting of $1 \mathrm{ml}$ of yellow-colored fraction and $100 \mathrm{mg}$ of $\mathrm{ADH}$ was incubated overnight at $4^{\circ} \mathrm{C}$. The reaction mixture was added to $10 \mu \mathrm{l}$ of $5 \mathrm{M}$ sodium cyanoborohydride in $1 \mathrm{~mol} / 1 \mathrm{NaOH}$ and incubated at $4^{\circ} \mathrm{C}$ for $3 \mathrm{~h}$ (Fig. 1(b)). The 
reaction mixture was equilibrated with $10 \mathrm{mM}$ phosphate buffer solution and filtered through the Sephadex G-25 column.

Subsequently, the cortisol was activated. A solution consisting of $5 \mathrm{mg}$ of cortisol21-hemisuccinate (086-05583, Wako Pure Chemical Industries, Ltd., Japan), $200 \mu \mathrm{l}$ of dimethyl formaldehyde, $200 \mu \mathrm{l}$ of 1,4-dioxane, $100 \mu \mathrm{l}$ of distilled water, $10 \mathrm{mg}$ of $\mathrm{N}$-hydroxysuccinimide, and $20 \mathrm{mg}$ of 1-ethyl-3-(3-dimethyl-amino-propyl) carbodiimide$\mathrm{HCl}$ was incubated overnight at $4^{\circ} \mathrm{C}$. The GOD-(ADH)-cortisol conjugate was synthesized by mixing $1 \mathrm{ml}$ of GOD-ADH with $500 \mu \mathrm{l}$ of activated cortisol, incubated overnight at $4{ }^{\circ} \mathrm{C}$, filtered through the Sephadex G-25 column, and then collected in vials at $1 \mathrm{ml}$ (Fig. 1(c)).

\subsection{Characteristics of GOD-cortisol conjugate}

The GOD enzyme activities of each $1 \mathrm{ml}$ of the filtered synthesized GOD-cortisol conjugate solution were measured. $\beta$-D-glucose was used as the substrate for GOD, the activity of which was measured by an absorbance-based technique in accordance with the following reactions:

GOD

$$
\beta \text {-D-glucose }+\mathrm{O}_{2}+\mathrm{H}_{2} \mathrm{O} \rightarrow \text { D-Glucono- } \delta \text {-lactone }+\mathrm{H}_{2} \mathrm{O}_{2}
$$

Peroxidase

$$
2 \mathrm{H}_{2} \mathrm{O}_{2}+4 \text {-aminoantipyrine }+ \text { Phenol } \rightarrow \text { Quinoneimine dye }+4 \mathrm{H}_{2} \mathrm{O}
$$

The appearance of the quinoneimine dye formed by coupling with 4-aminoantipyrine and phenol was measured at $500 \mathrm{~nm}$ using a spectrophotometer (V-570, JASCO Co., Japan). GOD enzyme activity was determined using the "Amano method" (Amano Enzyme Inc., Japan, http://www.amano-enzyme.co.jp/eng/index.html). GOD assay solution (pH 7) was prepared by mixing $2 \mathrm{ml}$ of phenol-buffer solution, $0.5 \mathrm{ml}$ of $100 \mathrm{mg} / \mathrm{ml}$ D-glucose, $0.5 \mathrm{ml}$ of $25 \mathrm{U} / \mathrm{ml}$ purpurogallin, and $0.1 \mathrm{ml}$ of $4 \mathrm{mg} / \mathrm{ml}$ 4-aminoantipyrine. The phenol-buffer solution consisted of $3 \%$ of $50 \mathrm{mg} / \mathrm{ml}$ phenol solution, $3 \%$ of $50 \mathrm{mg} /$ $\mathrm{ml}$ triton $\mathrm{X}-100$, and $94 \%$ of $100 \mathrm{mM}$ phosphate buffer $\left(\mathrm{KH}_{2} \mathrm{PO}_{4}-\mathrm{NaOH}, \mathrm{pH}\right)$. The glucose concentration in the GOD assay solution was $1.6 \mathrm{~g} / \mathrm{dl}$. After mixing $3.1 \mathrm{ml}$ of the GOD assay solution and $0.1 \mathrm{ml}$ of the GOD-cortisol conjugate solution, the change in absorbance was analyzed at $37^{\circ} \mathrm{C}$ for $5 \mathrm{~min}$. The definition of one unit of activity (U) per volume of enzyme solution (ml) is that this activity oxidizes $1 \mu \mathrm{mol}$ of $\beta$-D-glucose per minute. The protein was measured by the Lowry method using a colorimetric total protein assay kit (RC DC protein assay, Bio-Rad Laboratories, Inc., CA).

To verify the characteristics of the GOD-cortisol conjugate, the molecular weight of the resultant product was measured by sodium dodecyl sulfate-polyacrylamide gel electrophoresis (SDS-PAGE). Unmodified GOD was used as a molecular weight standard. A solution consisting of $4.5 \mu 1$ of GOD-cortisol conjugate, $0.5 \mu 1$ of 2-mercaptoethanol, $5 \mu \mathrm{l}$ of $2 \times$ sample buffer consisting of $50 \%$ tris- $\mathrm{HCl}(0.25 \mathrm{M}, \mathrm{pH}$ 6.8 ), $4 \%$ SDS, $11 \%$ sucrose, $0.4 \%$ bromophenol blue, and distilled water was incubated at $95^{\circ} \mathrm{C}$ for $3 \mathrm{~min}$. This solution was subjected to $10 \%$ SDS-PAGE (Ready Gels J, 
161-J320, Bio-Rad Laboratories, Inc., CA) at $20 \mathrm{~mA}$ for $90 \mathrm{~min}$. The gels were stained with coomassie brilliant blue.

Next, the concentration of the GOD-cortisol conjugate was measured on the basis of an antigen-antibody reaction using cortisol antigen. The antigen-antibody reaction of the GOD-cortisol conjugate and cortisol antibody was measured using a cortisol-antibodycoated ELISA plate (1-3002, Salimetrics LLC, PA). The GOD-cortisol conjugate was added at $25 \mu \mathrm{l}$ to each well in the plate. Immediately after, to bind the GOD-cortisol conjugate (antigen) to the cortisol antibody, the plate was incubated at $37^{\circ} \mathrm{C}$ for $1 \mathrm{~h}$. After the plate was washed with wash buffer, $300 \mu \mathrm{l}$ of GOD enzyme assay solution was added to each well, followed by incubation at $37^{\circ} \mathrm{C}$ for $30 \mathrm{~min}$. The GOD enzyme activity of the GOD-cortisol conjugate was determined from the absorbance for each concentration. The optical density was measured at $490 \mathrm{~nm}$ using a fluorescence plate reader (Wallac 1420 ARVO MX/Light, Perkin Elmer Inc., MA). A plate without cortisol antibody was used as the control.

\subsection{Test strip}

A disposable test strip $\left(5 \times 1.5 \times 50 \mathrm{~mm}^{3}\right)$ was fabricated by incorporating a sample pad $\left(5 \times 0.83 \times 10 \mathrm{~mm}^{3}\right.$, CFSP203000, Millipore Co., MA), a conjugate pad $(5 \times 0.41 \times$ $5 \mathrm{~mm}^{3}$, GFCP103000, Millipore Co.) containing $20 \mu \mathrm{l}$ of the GOD-cortisol conjugate, a nitrocellulose membrane $\left(5 \times 0.24 \times 50 \mathrm{~mm}^{3}\right.$, HF240MC100, Millipore Co. $)$ with the immobilized cortisol antibody (Murine Monoclonal Anti-Cortisol; MIC0202PG, Serady Inc., IN), and an absorbent pad $\left(5 \times 0.83 \times 5 \mathrm{~mm}^{3}\right.$, CFSP203000, Millipore Co.).

Upon application of $100 \mu \mathrm{l}$ of the cortisol solution to the sample pad $\left(t_{0}=0 \mathrm{~min}\right)$, any high-molecular-weight impurities are filtered out by the sample pad (Fig. 2(a)). Immediately thereafter, the sample dissolves the GOD-cortisol conjugate contained within the conjugate pad. The sample solution migrates laterally along the membrane by capillary action and reaches the test zone (Fig. 2(b)). Here, the target molecule (cortisol) contained within the sample solution reacts with the immobilized cortisol antibody through an antigen-antibody reaction. Owing to the competitive binding, the concentration of the trapped GOD cortisol conjugate is inversely proportional to the cortisol concentration in the sample. Next $\left(t_{1}=5 \mathrm{~min}\right), 40 \mu \mathrm{l}$ of the GOD enzyme assay solution is dropped on the strip and this produces a visible red band in the test zone. The intensity of the band is inversely proportional to the cortisol concentration in the sample and can be used for semiquantitative interpretation (Fig. 2(c)).

\subsection{Optical reader}

To estimate semiquantitatively the cortisol content, the observed quinoneimine dye band formed by the coupling of 4-aminoantipyrine and phenol is measured using an optical analyzer $\left(26.5 \times 25.5 \times 14.5 \mathrm{~cm}^{3}, 11 \mathrm{~kg}\right)($ Fig. 3(a)). The fabricated optical analyzer consists of a holder for inserting the test strip, a light-emitting diode (LED), a chargecoupled device image sensor (CCD) unit for measuring the optical density, a temperature control unit for verifying the ambient temperature, and an output display (Fig. 3(b)). The optical analyzer is connected to a personal computer (Dimension 2400, Dell Inc., TX) in order to control it. When the cortisol test strip is inserted, the LED illuminates the strip 
(a)

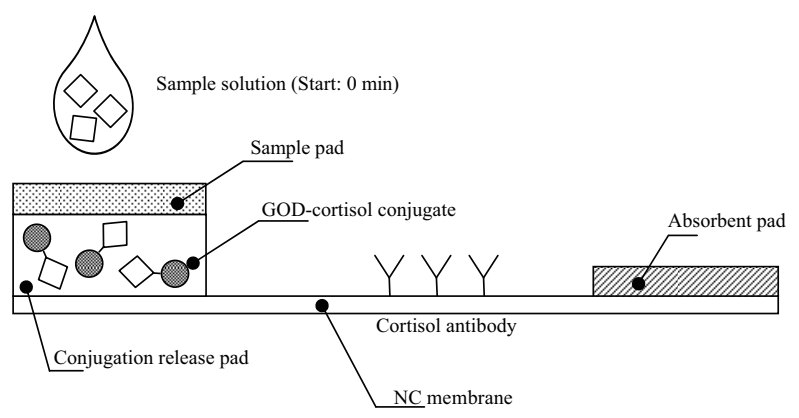

(b)

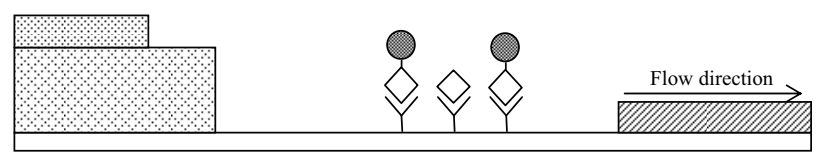

(c)

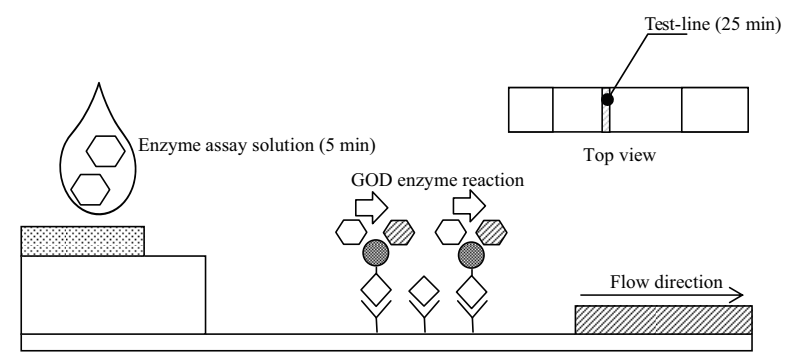

Fig. 2. Principle of immunochromatographic test strip-based biosensor for cortisol analysis. (a) Schematic of immunochromatographic test strip, (b) competitive reaction of cortisol and GODcortisol conjugate, and (c) coloring by GOD enzyme reaction.

and the CCD detects the test band (Fig. 3(c)). The density of the test line is measured using the $\operatorname{CCD}\left(t_{2}=25 \mathrm{~min}\right)$ at a wavelength of $520 \mathrm{~nm}$ and the reflectance $\mathrm{r}$ is calculated as

$$
r=S / S_{0}
$$

where $S$ is the amount of light received after the reaction, and $S_{0}$ is the amount of light received before the reaction.

The signal (reflectance $r$ ) detected using the optical analyzer is not only proportional to the cortisol concentration, but also inversely proportional to the concentration of the GOD-cortisol conjugate. Thus, the cortisor concentration can be calculated using a calibration curve of the reflectance relative to the cortisol concentration. The analytical accuracy of the cortisol biosensor was evaluated between $1-10 \mathrm{ng} / \mathrm{ml}$ using a standard cortisol solution (sample solution, Salimetrics LLC, PA). 


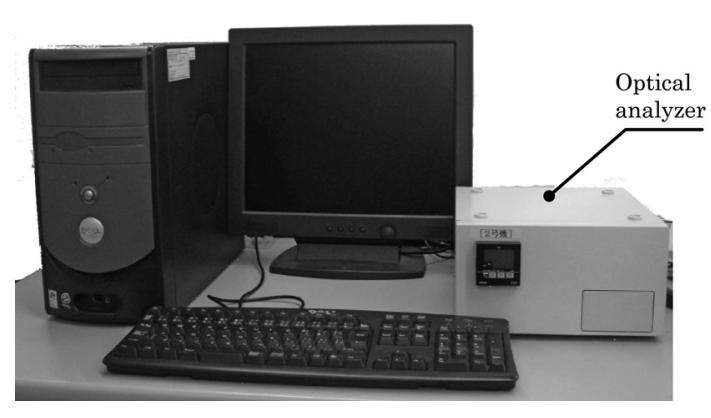

(a)

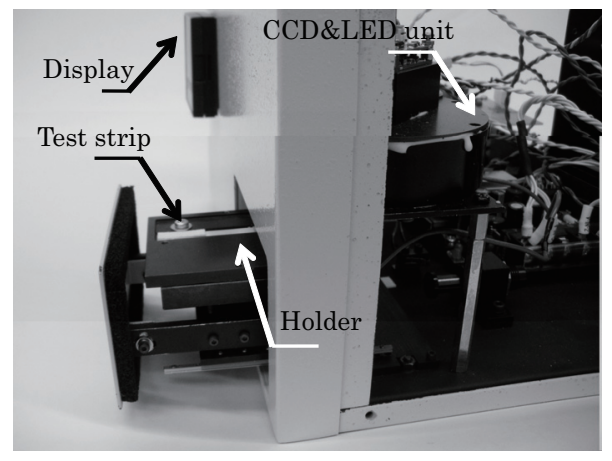

(b)

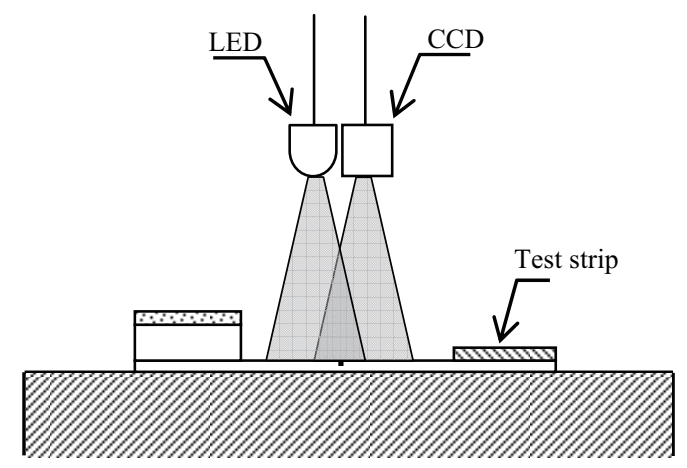

(c)

Fig. 3. External view of an optical analyzer used for cortisol analysis. (a) Overview of the optical analyzer connected to a personal computer $\left(260 \times 150 \times 290 \mathrm{~mm}^{3}, 6 \mathrm{~kg}\right)$, (b) external view of the optical analyzer without a cover, and (c) measurement principle.

\section{Results and Discussion}

\subsection{Characteristics of GOD-cortisol conjugate}

The highest GOD enzyme activity of the synthesized GOD-cortisol conjugate fraction solution was $91.2 \pm 10.8 \mathrm{U} / \mathrm{mg}(n=5)$. The GOD-cortisol conjugate and GOD migrated in the polyacrylamide gel (SDS-PAGE) with molecular masses of 200,000 and 75,000 Da, respectively. The molecular weights of each material were GOD, 75,000 $\mathrm{Da}$; cortisol, $414 \mathrm{~g} / \mathrm{mol}$ (=414 Da); and ADH, $174.2 \mathrm{~g} / \mathrm{mol}$ (=174.2 Da). Thus, the molecular weight of the GOD-cortisol conjugate is twice the predicted molecular weight $(75,560 \mathrm{Da})$, which is the sum of the molecular weights of the GOD, cortisol, and ADH. Multiple cortisol molecules appear to combine with one GOD molecule, and there may be cross-coupling of GOD molecules. This chemical phenomenon may potentially help improve the sensitivity of the cortisol analysis. 
The absorbances of the enzymatic reactions $(A b s)$ were $2.34,1.38,1.15,0.76,0.42$, and 0.31 , when the concentrations of the GOD-cortisol conjugate were 1.06, 0.53, 0.21, $0.16,0.053$, and $0.021 \mathrm{mg} / \mathrm{ml}$, respectively. The absorbances of the controls (Cont) were $1.42,0.78,0.88,0.40,0.24$, and 0.17 . Thus, $\triangle O D_{490}$ values $(A b s-C o n t)$ were $0.93,0.60$, $0.27,0.36,0.17$, and 0.14 , respectively (Fig. 4 ). The specificity of the antigen-antibody reaction induced was proportional to the concentration of the GOD-cortisol conjugate. These results identify the synthesized molecule as a GOD-cortisol conjugate, both by molecular weight and the specific detection of cortisol.

\subsection{Test strip}

The band was observed clearly when the cortisol concentration of the standard solution was less than $10 \mathrm{ng} / \mathrm{ml}$ (Fig. 5). The sample solution reached the test line $10 \mathrm{~s}$ after dropping the solution. Three minutes after the addition of the GOD enzyme assay solution, a color change reaction at the test line was observed. These results indicated the functionality of the fabricated test strip as a flow channel for lateral fluid flow. The concentration of salivary glucose was reported to be approximately $4 \mathrm{mg} / \mathrm{dl}$ at most, ${ }^{(21)}$ and is approximately $1 / 400$ of the concentration of glucose in the GOD assay solution $(1.6 \mathrm{~g} / \mathrm{dl})$. Thus, it can be considered that salivary glucose does not affect the accuracy of the cortisol biosensor.

\subsection{Cortisol biosensor}

When $0,1,5$, and $10 \mathrm{ng} / \mathrm{ml}$ standard cortisol solutions were applied to the sample pad, the reflectances (mean $\pm \mathrm{SD}$ ) of the test band were $0.466 \pm 0.018,0.538 \pm 0.016,0.551$ \pm 0.018 , and $0.635 \pm 0.015$, respectively. The coefficients of variation (CVs) were 3.8, 2.9, 3.3 , and 3.1\%, respectively (Fig. 6). With regard to the calibration curve for the cortisol test strip, the $R^{2}$ value was 0.90 ; the relationship between the cortisol concentration

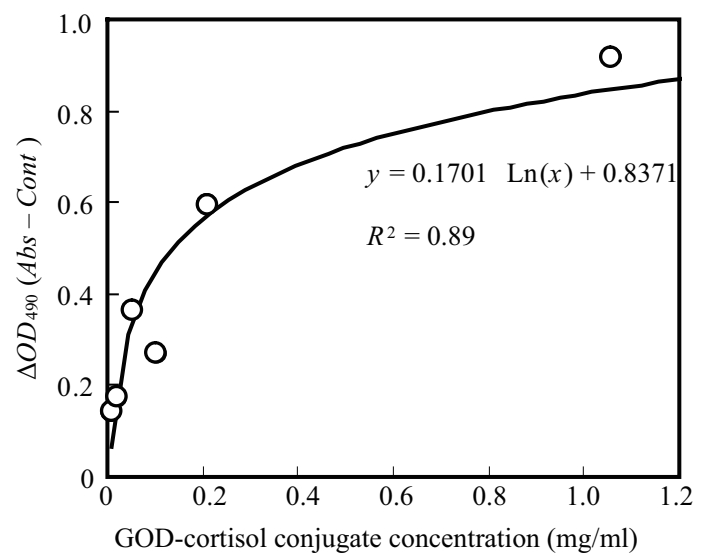

Fig. 4. Concentration characteristics of the GOD-cortisol conjugates. $\triangle O D_{490}$, absorbance of enzyme reaction with cortisol antibody $(A b s)$ - without cortisol antibody $(C o n t)$. 


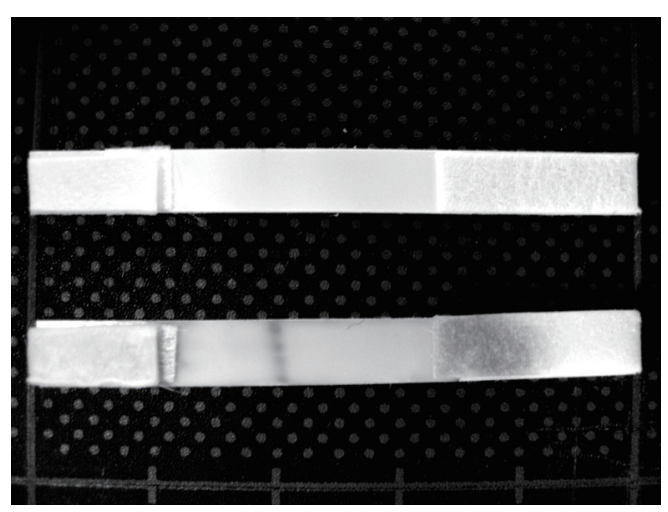

Fig. 5. External view of the test strips before (upper) and $25 \mathrm{~min}$ after (lower) application of the sample solution.

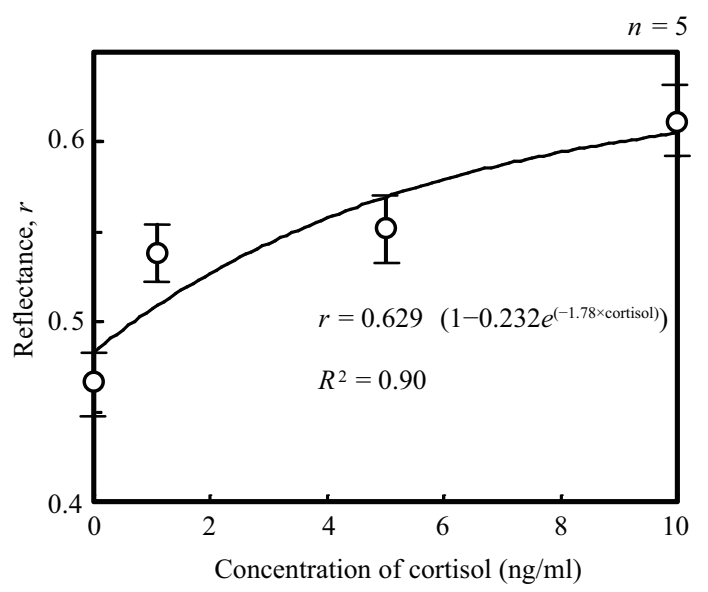

Fig. 6. Calibration curve of the test strip for cortisol analysis.

and reflectance was $r=0.629\left(1-0.232 e^{(-1.78 \times \text { cortisol })}\right)$. Considering the error bar (SD) of reflectances, the cortisol concentrations were distinguished by 0,5 , and $10 \mathrm{ng} / \mathrm{ml}$. However, the cortisol concentration between 1 and $5 \mathrm{ng} / \mathrm{ml}$ was not distinguished. The effect of blocking treatment of the membrane is the subject of a future study. Thus, it was indicated that a three-scale semiquantitative analysis of cortisol concentrations such as low, middle, and high between 1 and $10 \mathrm{ng} / \mathrm{ml}$ could be possible in $25 \mathrm{~min}$ from the dropping of the cortisol solution on the test strip to the analysis. The measurement time was equivalent to the time that patients spend in the hospital. The cortisol concentrations in the plasma and urine are approximately ten times higher than that in saliva. The fabricated cortisol biosensor can be used to analyze the cortisol concentrations in the plasma and urine by controlling the sensitivity. The establishment of the threshold levels will follow the diagnosis standard of each stress-related disease such as IBS, CFS, and 
PTSD. The salivary cortisol (20:00h) level is significantly lower in an IBS patient, 3.57 $\mathrm{ng} / \mathrm{ml}$, than in a healthy subject, $6.40 \mathrm{ng} / \mathrm{ml} .{ }^{(8)}$ The salivary cortisol level in the morning or bedtime would be a useful index for the diagnosis of stress-related diseases.

\section{Conclusions}

To replace time-consuming laboratory analysis and facilitate point-of-care testing of salivary cortisol, we have developed an immuno-chromatographic biosensor system utilizing small disposable test strips $\left(5 \times 1.5 \times 50 \mathrm{~mm}^{3}\right)$ and a desktop-based reader $\left(26.5 \times 25.5 \times 14.5 \mathrm{~cm}^{3}\right)$. Capitalizing on the speed and selectivity of immunodetection approaches, we successfully synthesized a glucose oxidase (GOD)-cortisol conjugate and verified its characteristics through molecular weight determination and its specific binding to cortisol. The cortisol biosensor system prototype allowed a three-scale semiquantitative analysis of cortisol concentrations such as low, middle, and high between 1 and $10 \mathrm{ng} / \mathrm{ml}$ in $25 \mathrm{~min}$ from the dropping of the cortisol solution on the test strip to the analysis. To apply this sensor to stress-related diseases such as IBS, the pathogenic relationship between cortisol and stress should be analyzed in a case control study. Our findings indicate the potential utility of our immuno-chromatographic system for developing point-of-care biosensors for measuring cortisol. Field studies are necessary to evaluate the accuracy of the fabricated cortisol biosensor for stress-related diseases.

\section{Acknowledgement}

This research was supported by Grant Number 1U01-DAO23815 from the NIH/ National Institute on Drug Abuse (NIDA), USA and the Comprehensive Support Programs for Creation of Regional Innovation from Japan Science and Technology Agency, Japan.

\section{References}

1 D. Malamud: J. Am. Dent. Assoc. 137 (2006) 284.

2 L. A. Tabak: Ann. N. Y. Acad. Sci. 1098 (2007) 7.

3 A. Segal and D. T. Wong: Eur. J. Dent. Educ. 12 (Suppl 1) (2008) 22.

4 D. H. Hellhammer, S. Wust and B. M. Kudielka: Psychoneuroendocrinology 34 (2009) 163.

5 J. P. Kahn, D. R. Rubinow and C. L. Davis: Biol. Psychiatry 23 (1998) 335.

6 R. F. Vining, R. A. McGinley, J. J. Maksvytis and K. Y. Ho: Ann. Clin. Biochem. 20 (1983) 329.

7 E. Aardal and A. C. Holm: Eur. J. Clin. Chem. Clin. Biochem. 33 (1995) 927.

8 F. R. Patacchioli, L. Angelucci, G. Dellerba, P. Monnazzi and O. Leri: J. Endocrinol. Invest. 24 (2001) 173.

9 W. K. Jerjes, T. J. Peters, N. F. Taylor, P. J. Wood, S. Wessely and A. J. Cleare: J. Psychosomatic. Res. 60 (2006) 145.

10 L. W. Hawk, A. L. Dougall, R. J. Ursano and A. Baum: Psychosom. Med. 62 (2000) 423. 
11 R. L. Burr, M. E. Jarrett, K. C. Cain, S. E. Jun and M. M. Heitkemper: Neurogastroenterol. Motil. Jul 1 (2009) (Epub ahead of print).

12 M. Ihara, T. Suzuki, N. Kobayashi, J. Goto and H. Ueda: Anal. Chem. 81 (2009) 8298.

13 C. J. Cook: Nat. Biotechnol. 15 (1997) 467.

14 M. Mirasoli, S. K. Deo, J. C. Lewis, A. Roda and S. Daunert: Anal. Biochem. 306 (2002) 204.

15 W. Leung, P. Chan, F. Bosgoed, K. Lehmann and I. Renneberg: J. Immunol. Methods. 281 (2003) 109.

16 R. C. Stevens, S. D. Soelberg, S. Near and C. E. Furlong: Anal. Chem. 80 (2008) 6747.

17 M. Jia, Z. He and W. Jin: J. Chromatogr. A 966 (2002) 187.

18 J. D. Netwman and A. P. F. Turner: Biosens. Bioelectron. 20 (2005) 2435.

19 H. Hosoda, M. Itoh, R. Tsukamoto and T. Nambara: Chem. Pharm. Bull. 37 (1981) 859.

20 A. Basu, T. G. Shrivastav and K. P. Kariya: Clin. Chem. 49 (2003) 1410.

21 R. B. Northrop: Noninvasive Instrumentation and Measurement in Medical Diagnosis (CRC Press LLC, Washington D.C., 2001) Chap. 8. 